\title{
Evaluation of economically valuable traits of the columnar variety Poesia and the prospects of its use in breeding
}

\author{
S.A. Korneeva, E.N. Sedov, and T.V. Yanchuk ${ }^{*}$ \\ FSBSI Russian Research Institute of Fruit Crop Breeding, Orel, Russia
}

\begin{abstract}
One of the most promising forms of apple trees for superintensive gardens on a new genetic basis is the columnar apple tree. Within the framework of the breeding program of the Russian Research Institute of Fruit Crop Selection, 5 columnar apple tree varieties were created and released, one of which is the Poesia variety. The article presents an assessment of the suitability of the columnar apple tree variety Poesia for intensive gardening and prospects of its use in breeding work to create competitive varieties of the new generation. According to complex of economically valuable traits, the variety is characterized by winterhardiness, early maturation, high yield - for the first 7 years of fruiting, the average variety yield on dwarf rootstock $62-396$ was $41.6 \mathrm{t} / \mathrm{ha}$, immunity to scab (gene Rvi6), greatly reducing the pesticide load in the garden. The fruits have an attractive appearance, which is rated with 4.4 points (on a five-point scale), sweet and sour taste (4.3 points). It was established that the Poesia variety is a donor of columnar shape (Co gene) and immunity to scab (Rvi6 gene). With its participation, eight selected forms and one elite seedling have already been created.
\end{abstract}

\section{Introduction}

The attractiveness of columnar apple tree is caused by the early fruiting, yield of the variety, minimization of costs for pruning in columnar gardens. Columnar shape is a genetically determined ( $C o$ gene) trait of an apple tree, which is phenotypically manifested by a special type of tree growth [3]. The habitus of the columnar shape of apple tree is characterized by close internodes (when breeding for columnar shape, only those seedlings whose compactness does not exceed 2.5 are subject to breeding), reduced shoot-forming ability and vertical growth character [2, 12]. All columnar apple tree varieties have a predominantly annular type of fruiting. The economically valuable traits of columns include a high rate of early maturity (columnar garden in the third year after planting gives an industrial yield), record values for yield per unit area (about $100 \mathrm{t} / \mathrm{ha}$ ), obtained due to the high density of tree planting in a columnar plantation, annual stable fruiting (due to the alternation of fruit-bearing spurs) $[3,12]$.

\footnotetext{
*Corresponding author: yanchuk@vniispk.ru
} 
The columnar shape of apple tree is a promising breeding object, since the Co gene belongs to the main genes, which makes it easier to combine it with the genes of economically valuable traits (immunity to scab, powdery race, winter hardiness, largefruiting). Its linkage with negative cross characters was not noted by researchers $[13,14]$.

Within the framework of a large-scale program of import substitution in resource markets and increasing the competitiveness of agricultural products, the role of domestic varieties suitable for intensive cultivation technologies and having a high potential for adaptability and environmental safety has increased. Improving the assortment of apple trees, creating varieties with specified economically valuable characteristics is the main task of the breeding institution. In this regard, in the presented studies, we set the goal to give an estimated characteristic of the columnar variety Poesia as a promising variety for industrial gardening and as a donor of economically valuable traits for breeding.

The Russian Research Institute of Fruit Crop Breeding actively conducts breeding work in current areas, one of which is the creation of columnar apple tree varieties for super-intensive gardens. Within this direction, columnar apple tree varieties (Priokskoe, Poesia, Vostorg, Girlyanda, Orlovskaya Yesenia) have already been created and released, and a number of selected forms and promising hybrides have been obtained [8]. Successful work in this direction is also being carried out in other scientific institutions. There are known columnar varieties of selection of the FRC of Horticulture: Valyuta, Dialog, Vasyugan, Ostankino, President, Malyukha, Lukomor, Triumph, Chervonets. In the FRC n.a. Michurin columnar varieties of apple trees Geyser, Gothica, Cascad, Cornet, Stela, Strela were created [7]. M.V. Kachalkin created the Moscovskoye Ozherelye, Yantarnoye Ozherelye varieties. Promising forms were obtained by breeders in the Kabardino-Balkaria and Bashkiria [6].

Despite the active purposeful breeding work on the creation of columnar apple tree varieties, the share of these varieties in the existing assortment is small $(6 \%$ of the total released apple tree assortment). In this regard, there is a wide prospect for creating adaptive, high-yield, deep-winter columnar apple tree varieties with fruits of dessert taste. The involvement of released and well-studied columnar varieties in breeding as donors of economically valuable traits is a promising and effective method.

\section{Research methods}

The studies were conducted using generally accepted methods $[9,10]$.

Determination of the growth strength (spread). The ranking of apple tree varieties by growth strength is carried out in accordance with tree height value.

- The group of very dwarf varieties includes varieties which tree height does not exceed $2 \mathrm{~m}$.

- The tree height of dwarf varieties is $2-3 \mathrm{~m}$.

- In semi-dwarf varieties, the tree height is 3-4 $\mathrm{m}$.

- Medium-sized plants have a height of 4-5 $\mathrm{m}$.

- In strong-growing varieties, the tree height is $5-7 \mathrm{~m}$.

- Very strong-growing trees reach a height of more than $7 \mathrm{~m}$.

Study of shoot-forming ability. The shoot-forming ability and the parent branches union determine the type of crown (broom-shaped, pyramidal, wide-pyramidal, obypyramidal, rounded, wide-rounded, plain-rounded, cemuous. The crown can be very thick, dense, medium-thick, thin. The branch union can be acute, straight or close to straight, obtuse. The shoot-forming ability, branch union, type of crown of the variety is determined visually when conducting records in the garden as part of the primary variety study. 
Calculation of variety yield. The study of the apple tree yield includes accounting for the yield per tree in $\mathrm{kg}$ with further recalculation per unit area and is expressed in $\mathrm{t} / \mathrm{ha}$.

Determination of leaf coverage degree. The leaf size, their number and leaf area on the tree affect the variety productivity. The following pattern is established - a decrease in the leaf surface leads to a proportional decrease in yield (so a decrease in the leaf surface by $25 \%$ also reduces the yield by $25 \%$ ). A comparative assessment of the leaf coverage of columnar apple tree variety with a variety with voluminous crown was carried out by determining the leaf area per length unit of the fruit-bearing shoot. To determine the leaf area per length unit of the shoot, the number of leaves per shoot was counted and the average leaf area was calculated. The leaf area was calculated by weight [11].

20 whole leaves and cuttings of 20 leaves were weighed ( 3 cuttings with a diameter of 2 $\mathrm{cm}$ were made in each leaf, one of which includes a central vein). Using data on the cutting area, cutting and whole leaves mass, the whole leaves area was calculated.

The evaluation of fruit taste and appearance was performed by the decision of experts within the framework of the taste panel meeting and was expressed in a point system, ranging from 1 point to 5 points $[9,10]$.

The study of variety winter hardiness was carried out by observations in the field and modeling of damaging factors under controlled conditions.

Accounting for the total degree of tree freezing was carried out in the spring after flowering (end of May). The overall degree of freezing is assessed on a five-point scale. Based on long-term data for the period from 2006 to 2013 (including years with severe winters), the studied variety is characterized by winter hardiness degree. On this basis, varieties are ranked in 5 groups: high-hardy, winter-hardy, medium-hardy, low-hardy, not winter-hardy.

The method for assessing winter hardiness of varieties under controlled conditions accelerates the determination of the potential of a variety according to four components of winter hardiness: resistance to early winter frosts (for the Central Chernozem region, this temperature is $-25^{\circ} \mathrm{C}$ ), resistance to maximum negative temperatures $\left(-40^{\circ} \mathrm{C}\right)$, ability to maintain resistance during thaws (after holding samples in a thaw mode at low positive temperatures $+2^{\circ} \mathrm{C},+5^{\circ} \mathrm{C}$ they are frozen at a temperature of $-25^{\circ} \mathrm{C}$ ), resistance to return frost (after holding samples in a thaw mode at low positive temperatures $+2^{\circ} \mathrm{C},+5^{\circ} \mathrm{C}$ and hardening, they are exposed to freeze at a temperature of $-35^{\circ} \mathrm{C}$ ).

Assessment of damage to varieties is carried out by the degree of tissue damage (browning) of annual shoots using a binocular microscope MBS-2 on a scale from 0 (no damage) to 5 points (death of tissues and buds after regrowth).

The reliability of all the collected experimental data is confirmed by mathematical and statistical processing carried out using variance analysis [1] and a computerized MS Excel program.

\section{Results}

One of the first zoned columnar breeding varieties of VNIISPK is the Poesia variety. It combines the columnar $(\mathrm{Co})$ and scab immunity (RviO) genes in its genotype. The variety was obtained in 1996 from free pollination of the columnar scab-immune form 224-18 (SR0523 $\times$ Vazhak). In 2015, it was included in the State Register of Breeding Achievements according to the complex of economically valuable traits.

\subsection{Economic and biological characteristics of the Poesia variety}

\subsubsection{Biological features of the variety.}


Trees of the Poesia variety are of columnar habitus. The height of the tree at 6 years of age on dwarf rootstock 62-396 is $163 \mathrm{~cm}$, on dwarf rootstock insertion 3-17-38-210 cm, in the crown of semi-dwarf rootstock 3-4-98 - $224 \mathrm{~cm}$. Fruiting is mainly focused on simple and complex spurs, as well as on dards.

The variety productivity depends on the leaf surface area. In columnar varieties, high productivity is caused by a large leaf coverage. So the Poesia variety is characterized by short internodes and large dark green leaves. The degree of compactness (the ratio of internode length to shoot thickness) is 1.5 , the leaf area is $59.2 \mathrm{~cm}^{2}$. The area of the leaf surface per shoot length unit is one of the most significant indicators of the variety productivity. In the Poesia variety, this indicator is $787.4 \mathrm{~cm}^{2}$ (on a 20 -centimeter shoot), which is 3 times more than the value of a similar indicator in the variety with a voluminous crown Sinap Orlovsky $\left(263.4 \mathrm{~cm}^{2}\right)$.

The shoot-forming ability of the columnar apple tree is low, but this indicator varies by variety. When planning a super-dense columnar garden with plant placement (14000-20000 plants per hectare), varieties with low shoot-forming ability are recommended, which allow not to thicken the planting and reduce the cost of tree pruning. The average number of lateral shoots in the Poesia variety is 1.5 pieces per tree - this is the average value of this indicator among the 10 studied columnar varieties (Priokskoe, Poesia, Vostorg, Girlyanda, Orlovskaya Yesenia, Sozvezdie, Pamyati Blynskogo, Moscovskoye Ozherelye, Valyuta, Zvezda Efira). The branches branch off at straight angles and when forming large crown plants, the tree takes on a pyramidal crown shape.

The adaptability of the variety (winter hardiness, resistance to common diseases) is an important breeding feature that affects its widespread introduction in a particular area of horticulture.

Unfavorable winter conditions are one of the limiting factors for the spread of new apple tree varieties in central Russia. In this regard, an important assessment of columnar apple tree varieties is the level of their winter hardiness. Taking into account the degree of freezing of the Poesia variety in the field shows that even in cold winters with temperatures below the long-term average (in some years the temperature dropped to $-34.2^{\circ} \mathrm{C}$ ), the damage was reversible and did not affect the overall condition of the trees. Accelerated assessment of the frost resistance of the Poesia variety under controlled conditions showed that its winter hardiness is at the control variety level. As a control variety, the columnar Valyuta (breeding of the FRC of Horticulture) - one of the first released columnar varieties.

Resistance to the lowest possible temperatures in the middle of winter (in the middle zone of Russia it is minus $38^{\circ}-40^{\circ} \mathrm{C}$ ) is the main limiting feature of any variety that affects its introduction in a particular gardening zone. In this regard, significant indicators are the degree of damage to vegetative buds, bark and wood when modeling critical frosts.

Modeling of critical frosts (II component of winter hardiness) showed that in the columnar variety Poesia, damage degree of vegetative buds was 2.6 points, in the control variety Valyuta - 2.5 points. The bark is characterized by a higher frost resistance - all damage was reversible. The degree of bark damage in the Poesia variety is 2.0 points, in the Valyuta variety - 1.8 points. Wood damage in the Poesia variety was reversible - the damage degree was 1.9 points; in the Valyuta variety these damages were more severe -2.5 points.

Within the framework of organic gardening development and general ecologization of agriculture, the creation of apple tree varieties with monogenic resistance to scab is necessary.

One of the parent forms of the Poesia variety is a Rvi6 gene donor, which provides monogenic resistance to scab [5]. The molecular genetic analysis confirmed that the dominant allele of the Rvi6 gene is present in the variety genome. 


\subsubsection{Economically valuable qualities of the Poesia variety.}

Early maturing variety. It begins to bear fruit in the third year after planting on the dwarf rootstock 62-396, on insertions of dwarf rootstocks 3-17-38 and 62-396, as well as on a skeletonizer of the semi-dwarf rootstock 3-4-98. The variety yield for the first seven years of fruiting in the crown of the semi - dwarf rootstock 3-4-98 is $23.6 \mathrm{t} / \mathrm{ha}$ (with a planting density of 3333 tree/ha), on the dwarf rootstock 62-396-41.6 t/ha (14000 tree/ha) [3].

Fruits of medium weight $(140 \mathrm{~g})$ are with a cover color in the form of a blurred brownish-red blush on most of the fruit. For the attractiveness the fruit is estimated at 4.4 points (on a five-point scale). The fruit pulp is greenish, pungent, fine-grained, juicy. Sweet and sour taste is estimated at 4.3 points.

\subsection{The prospects of the Poesia variety as the initial form for breeding}

The Poesia variety is a donor of the columnar crown habitus and immunity to scab (Rvi6 gene) in the breeding program. It is included in several breeding areas; a number of hybrid families of different origins have been obtained with its inclusion (Figure 1).

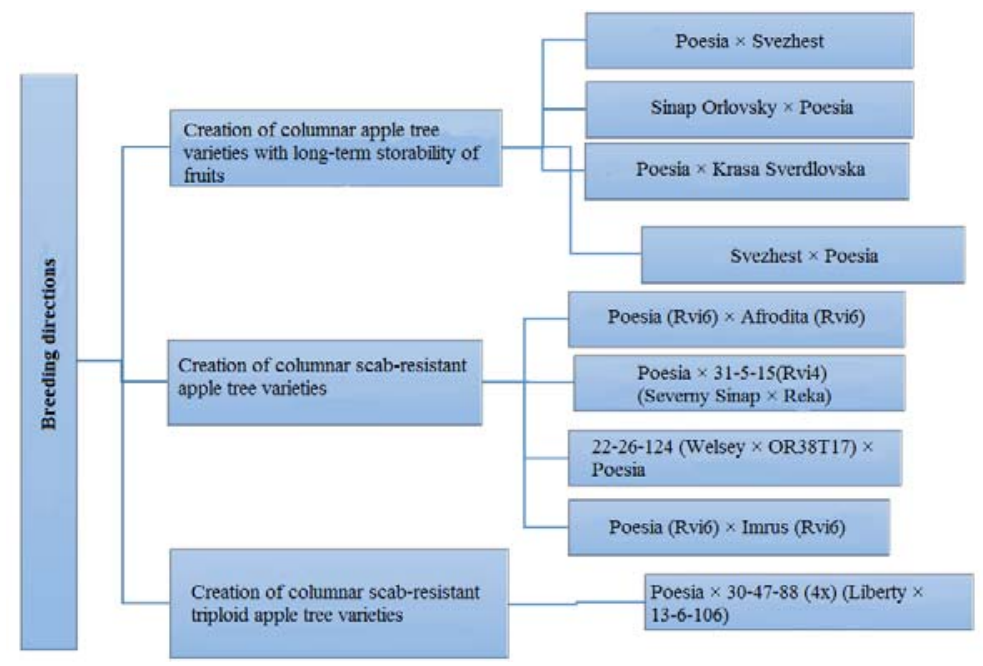

Fig. 1. Diagram of the breeding direction for creation of new columnar apple tree varieties.

From a large hybrid progeny of the Poesia variety, the genotypes of two families of 2010 cross with the following origin were analyzed: Poesia $\times 30-47-88(4 x)$ (Liberty $\times 13-$ 3-106) and 22-26-124 (Welsey $\times$ OR38T17) $\times$ Poesia.

Hybridological analysis of the Poesia $\times 30-47-88(4 x)$ (Liberty $\times 13-3-106)$ family shows that the splitting on the basis of columnar structure is traced in the ratio 1:1. Also in the analyzed family, the Co gene with Rvi6 gene linkage is noted in $78 \%$ of seedlings.

The form $30-47-88$ is a donor of diploid gametes; as a result, $72 \%$ of columnar seedlings are triploids, $20 \%$ of hybrids in the family combine three traits in their genotype at the same time: a triple set of chromosomes, the Co and Rvi6 genes.

In the family 22-26-124 (Welsey $\times$ OR38T17) $\times$ Poesia, $64.3 \%$ of hybrids are columnar, $4 \%$ of which have immune to scab (Rvi6 gene).

A preliminary assessment of the economic and biological characteristics of 235 seedlings allowed to distinguish one genotype for the elite and eight for the selected ones (Table 1). 
Table 1. Characteristics of elite and selected columnar genotypes.

\begin{tabular}{|c|c|c|c|c|}
\hline $\begin{array}{c}\text { Breeding } \\
\text { number }\end{array}$ & Origin & $\begin{array}{l}\text { Seedling } \\
\text { category }\end{array}$ & $\begin{array}{l}\text { Seedling genotypic } \\
\text { features } \\
\end{array}$ & Brief fruit description \\
\hline 295 & \multirow{8}{*}{$\begin{array}{l}\text { Poesia } \times \\
30-47-88 \\
(4 x) \\
\text { (Liberty } \times \\
13-6-106)\end{array}$} & Elite & $\begin{array}{l}\text { The genotype } \\
\text { combines column- } \\
\text { shape (Co gene), }\end{array}$ & $\begin{array}{l}\text { The weight of the fruit is } 150 \mathrm{~g} \text {, the } \\
\text { appearance of the fruit is estimated at } 4.5 \\
\text { points, sweet and sour taste of fruits }-4.4 \\
\text { points. }\end{array}$ \\
\hline $35-1-185$ & & Selected & $\begin{array}{l}\text { scab Immunity } \\
\text { (Rvi6 gene), and } \\
\text { triple set of } \\
\text { chromosomes }\end{array}$ & $\begin{array}{l}\text { The weight of the fruit is } 150 \mathrm{~g} \text {, the } \\
\text { appearance of the fruit is estimated at } 4.5 \\
\text { points, sweet and sour taste of fruits }-4.3 \\
\text { points. }\end{array}$ \\
\hline $35-1-86$ & & Selected & \multirow{4}{*}{$\begin{array}{l}\text { The genotype } \\
\text { combines column- } \\
\text { shape (Co gene) } \\
\text { and scab immunity } \\
\text { (Rvi6 gene) }\end{array}$} & $\begin{array}{l}\text { The weight of the fruit is } 160 \mathrm{~g} \text {, the } \\
\text { appearance of the fruit is estimated at } 4.5 \\
\text { points, taste - } 4.3 \text { points. }\end{array}$ \\
\hline $35-1-90$ & & Selected & & $\begin{array}{l}\text { The weight of the fruit is } 150 \mathrm{~g} \text {, the } \\
\text { appearance of the fruit is estimated at } 4.5 \\
\text { points, sweet and sour taste of fruits }-4.4 \\
\text { points. }\end{array}$ \\
\hline $35-1-144$ & & Selected & & $\begin{array}{l}\text { The weight of the fruit is } 140 \mathrm{~g} \text {, the } \\
\text { appearance of the fruit is estimated at } 4.5 \\
\text { points, sweet and sour taste of fruits }-4.3 \\
\text { points. }\end{array}$ \\
\hline $35-1-134$ & & Selected & & $\begin{array}{l}\text { The weight of the fruit is } 140 \mathrm{~g} \text {, the } \\
\text { appearance of the fruit is estimated at } 4.4 \\
\text { points, sweet and sour taste of fruits }-4.3 \\
\text { points. }\end{array}$ \\
\hline $35-1-106$ & & Selected & \multirow{2}{*}{$\begin{array}{l}\text { The seedling is } \\
\text { characterized by a } \\
\text { triple set of } \\
\text { chromosomes and } \\
\text { a columnar habitus } \\
\text { (Co gene) }\end{array}$} & $\begin{array}{l}\text { The weight of the fruit is } 160 \mathrm{~g} \text {, the } \\
\text { appearance of the fruit is estimated at } 4.5 \\
\text { points, sweet and sour taste of fruits }-4.3 \\
\text { points. }\end{array}$ \\
\hline $35-1-109$ & & Selected & & $\begin{array}{l}\text { The weight of the fruit is } 170 \mathrm{~g} \text {, the } \\
\text { appearance of the fruit is estimated at } 4.5 \\
\text { points, sweet and sour taste of fruits }-4.3 \\
\text { points. }\end{array}$ \\
\hline $35-2-198$ & $\begin{array}{l}22-26-124 \\
(\text { Welsey } \times \\
\text { OR38T17) } \\
\times \text { Poesia } \\
\end{array}$ & Selected & $\begin{array}{l}\text { Diploid columnar } \\
\text { (Co gene) seedling }\end{array}$ & $\begin{array}{l}\text { The weight of the fruit is } 130 \mathrm{~g} \text {, the } \\
\text { appearance of the fruit is estimated at } 4.5 \\
\text { points, sweet and sour taste of fruits - } 4.3- \\
4.4 \text { points. }\end{array}$ \\
\hline
\end{tabular}

\section{Conclusion}

The columnar variety Poesia for all characteristics (adaptability, early-matiration, yield, fruit quality) belongs to the varieties of the intensive type and is recommended for wide introduction into production.

The generalization of the obtained knowledge about the Poesia variety as the initial form for selection allows to characterize it as the columnar crown habitus donor and the source of economically valuable traits (early-matiration, taste and commercial qualities of fruits).

\section{References}

1. B.A. Dospekhov, Field Experience Methodology, 202 (1973)

2. M.V. Kachalkin, Izvestiya TSKhA, 1, 72 (2004)

3. V.V. Kichina, Columnar apple trees, 162 (2006)

4. $\quad$ S.A. Korneeva, E.N. Sedov, T.V. Yanchuk, Agrarian Science, 6, 99 (2020) 
5. A.S. Lyzhin, N.N. Savelyeva, Proceedings on Applied Botany, Genetics and Breeding, 18(1), 64 (2020)

6. G.A. Mansurov, Gardens of the Future: materials of the international scientific and practical conference dedicated to the 100th anniversary of the birth of $V$. I. Budagovsky, 165 (2011).

7. N.N. Savelyeva, A.S. Zemisov, Selection and variety breeding of garden crops, 12, 134 (2020)

8. E.N. Sedov; S.A. Korneeva, Z.M. Serova, Columnar apple tree in the intensive garden, 64 (2013)

9. $\quad$ Program and methods of fruit, berry and nut crops breeding, 504 (1995)

10. Program and methodology of variety study of fruit, berry and nut crops, 608 (1999)

11. S.S. Rubin, O.M. Danilevskaya Botanical Journal, 42(5), 34 (1957)

12. R.S. Shidakov, N.A. Kanetova, A.S. Sedakova, A.Kh. Pshenokov, Bulletin of the Russian Academy of Agricultural Sciences, 4, 21 (2014)

13. T. Bai, Y. Zhu, F. Fernandez-Fernandez, J. Keulemans, S. Brown, K. Xu, Mol Genet Genomics, 287, 437 (2012)

14. R. Vavra, J. Blazek, P. Vejl, M. Jonas, Holousy Ltd, 24, 187 (2015) 